University of Nebraska - Lincoln

DigitalCommons@University of Nebraska - Lincoln

Papers in Biotechnology

Chemical and Biomolecular Engineering

Research and Publications

July 1992

\title{
In Vitro Development of Zygotes from Prepubertal Gilts After Microinjection of DNA
}

\author{
B. L. Williams \\ Virginia Polytechnic Institute and State University \\ J. L. Johnson \\ Virginia Polytechnic Institute and State University \\ A. E.T. Sparks \\ Virginia Polytechnic Institute and State University \\ R. S. Canseco \\ Virginia Polytechnic Institute and State University \\ J. W. Knight \\ Virginia Polytechnic Institute and State University \\ See next page for additional authors
}

Follow this and additional works at: https://digitalcommons.unl.edu/chemeng_biotechnology

Part of the Biochemical and Biomolecular Engineering Commons

Williams, B. L.; Johnson, J. L.; Sparks, A. E.T.; Canseco, R. S.; Knight, J. W.; Velander, William H.; Page, R. L.; Drohan, W. N.; Young, J. M.; Pearson, R. E.; Wilkins, T. D.; and Gwazdauskas, F. C., "In Vitro Development of Zygotes from Prepubertal Gilts After Microinjection of DNA" (1992). Papers in Biotechnology. 2.

https://digitalcommons.unl.edu/chemeng_biotechnology/2

This Article is brought to you for free and open access by the Chemical and Biomolecular Engineering Research and Publications at DigitalCommons@University of Nebraska - Lincoln. It has been accepted for inclusion in Papers in Biotechnology by an authorized administrator of DigitalCommons@University of Nebraska - Lincoln. 


\section{Authors}

B. L. Williams, J. L. Johnson, A. E.T. Sparks, R. S. Canseco, J. W. Knight, William H. Velander, R. L. Page, W. N. Drohan, J. M. Young, R. E. Pearson, T. D. Wilkins, and F. C. Gwazdauskas 


\section{In Vitro Development of Zygotes from Prepubertal Gilts After Microinjection of DNA}

B. L. Williams*, A.E.T. Sparks*, R. S. Canseco*, J. W. Knight', J. L. Johnson", W. H. Velander, R. L. Pages, W. N. Drohan", J. M. Young ${ }^{1}$ R. E. Pearson*, T. D. Wilkins ${ }^{\ddagger}$, and F. C. Gwazdauskas*,2

Departments of *Dairy Science, ${ }^{\dagger}$ Animal Science, and ${ }^{\ddagger}$ Anaerobic Microbiology, College of Agriculture and Life Science, Virginia Agricultural Experiment Station, and \$Department of Chemical Engineering, College of Engineering, Virginia Polytechnic Institute and State University, Blacksburg 24061

\begin{abstract}
The effect of pronuclear microinjection of DNA and culture in excised mouse oviducts on the development of porcine zygotes was assessed in this study. Precocious ovulation was induced in prepubertal gilts with pregnant mare's serum gonadotrophin and hCG. Zygotes received either pronuclear microinjection of buffer alone, buffer containing a DNA construct, or no microinjection. Zygotes were cultured in vitro in either modified Krebs-Ringer bicarbonate medium (KRB) for $144 \mathrm{~h}$ or in mouse oviduct (MO) explant culture with KRB for 48, 72, 96, or $120 \mathrm{~h}$. Pronuclear microinjection of DNA resulted in a lower $(P<.05)$
\end{abstract}

cleavage index (CI) than did buffer or no microinjection (CI $2.16 \pm .10$ vs $2.80 \pm .13$ and $2.93 \pm .10$ ). The CI loss was greatest for DNA-injected zygotes at the two-cell stage of development. Coculture of zygotes in $\mathrm{MO}$ resulted in a higher $\mathrm{CI}(P<.01)$ than did culture in KRB. Culture in MO for $72 \mathrm{~h}$ was the most beneficial system compared with MO for 48,96 , or $120 \mathrm{~h}(P<.05$; CI $3.25 \pm .12$ vs 2.66 $\pm .18,2.79 \pm .14$, and $2.40 \pm .14$, respectively). Microinjection of DNA, not merely the mechanical procedure, was detrimental to early zygote development and may be the cause of low pregnancy rates.

Key Words: Pigs, Ova Culture, Transgenics

J. Anim. Sci. 1992. 70:2207-2211

\section{Introduction}

Research directed toward the production of transgenic animals is hampered by the inadequate in vitro development of zygotes. Petters et al. (1990) found 45 to $60 \%$ morula and blastocyst development from one- and two-cell porcine embryos cultured in Krebs-Ringer bicarbonate buffer (KRB) modified with glucose and glutamine. Others have reported comparable success with a modified Tyrode's medium supplemented with glucose and

\footnotetext{
${ }^{1}$ American Red Cross, Jerome H. Holland Laboratory, Plasma Derivative Laboratory, Rockville, MD 20855.

${ }^{2}$ To whom correspondence should be addressed.

Received October 25, 1991.

Accepted February 14, 1992.
}

glutamine (Hagen et al., 1991). However, other studies have shown that the use of media supplemented with porcine oviductal epithelial cells results in a greater proportion of two-cell porcine embryos developing to blastocyst than those in medium alone (62 vs $0 \%$; White et al., 1989). Krisher et al. (1989) used in vitro coculture of porcine zygotes for $6 \mathrm{~d}$ in explanted mouse oviducts. With this procedure, $78 \%$ of the zygotes reached the morula or blastocyst stage compared with $36 \%$ without oviducts. Although complex systems allow for increased in vitro development of one-cell zygotes, the optimal incubation times have not been established.

Our objective was to evaluate culture procedures and incubation times for zygote development after DNA microinjection. 


\section{Materials and Methods}

Precocious ovulation was stimulated in 40 prepubertal gilts 132 to $197 \mathrm{~d}$ of age. These gilts were classified as prepubertal by lack of observed estrus, age, weight, appearance of external genitalia, and herd history. Ovulation was synchronized by administration of 1,500 IU of pregnant mare's serum gonadotrophin (PMSG; Diosynth, Chicago, IL) followed by 500 IU of hCG (chorionic gonadotrophin, Lyphomed, Rosemont, IL; Pinkert et al., 1989) $68 \mathrm{~h}$ later. Gilts were bred by AI at 24 and $36 \mathrm{~h}$ after the injection of hCG followed by laparotomy 52 to $57 \mathrm{~h}$ after the injection.

Ovarian Observation and Zygote Collection. Surgical anesthesia was initiated with $1.5 \mathrm{~g}$ of Pentothal $^{\circledR}$ (Thiopental sodium, Abbott Laboratories, N. Chicago, IL) and maintained with halothane and nitrous oxide. Ovarian examination was accomplished after midventral laparotomy. The number of ovulations (corpora hemorrhagica, $\mathbf{C H}$ ) and unovulated follicles by diameter were recorded for each ovary. The oviducts of animals serving as donors were flushed by inserting a silastic cannula through the ostium of the infundibulum that reached approximately 6 to $8 \mathrm{~cm}$ into the ampulla of the oviduct. A two-piece collection cannula constructed of $1.98 \mathrm{~mm}$ i.d., $3.18 \mathrm{~mm} \mathrm{o.d.}$ tubing (Silastic ${ }^{\circledR}$, Dow Corning, Midland, MI) with a heat-flared funnel of $1.57 \mathrm{~mm}$ i.d., $2.08 \mathrm{~mm}$ o.d. polyethylene tubing (Intramedic ${ }^{\circledR}$, Clay Adams, Parsippany, NJ) fitted to the inserted end of the larger tubing was used to flush the oviducts. Two 10-mL volumes of PBS (Embryo Transfer Freezing Medium, Gibco, Grand Island, NY) supplemented with . $4 \%$ albumin, $10 \%$ newborn calf serum, and $.025 \mathrm{~g} / \mathrm{L}$ of antibiotic (Kanamycin Sulfate, Gibco; PBS1) were flushed through the oviduct. The flushing fluid was collected into sterile test tubes and transported to the laboratory at $37^{\circ} \mathrm{C}$.

Microinjection of DNA Construct. Zygotes were held in PBS 1 at $37^{\circ} \mathrm{C}$ during all manipulations. To allow for visualization of pronuclei, zygotes were centrifuged at $15,000 \times g$ for $8 \mathrm{~min}$ (Wall et al., 1985). After centrifugation, zygotes were examined for the presence of accessory sperm and pronuclear formation using Hoffman modulation optics $(200 \times)$. One-cell structures with no visible pronuclei were classified as unfertilized ova (UFO). Zygotes, as determined by presence of pronuclei, were randomly assigned to treatments of either no injection, buffer injection, or DNA injection. Buffer and DNA microinjection of zygotes was accomplished by inserting a glass injection pipette coutside tip diameter 1.0 to $1.5 \mu \mathrm{m}$ ) into the most visible pronucleus while the zygote was held stationary with suction from a blunt, polished holding pipette. One to two picoliters of buffer or
DNA construct was delivered using an automated microinjector (Model 5242; Eppendorf, Freemont, CA).

The DNA used for microinjection was a 9.3-kb (kilobase) fragment consisting of a genomic clone for the mouse whey acidic protein (WAP) gene (Andres et al., 1987) with the human protein $C$ (PC) cDNA inserted into the KpnI site of the first exon. The WAP PC construct was purified from the plasmid vector using HPLC (Velander et al., 1992). The DNA was in $10 \mathrm{mM}$ Tris- $\mathrm{HCl}$, $.25 \mathrm{mM}$ EDTA ( $\mathrm{pH} \mathrm{7.4)} \mathrm{buffer} \mathrm{at} \mathrm{a} \mathrm{concentration} \mathrm{of} 5 \mu \mathrm{g} / \mathrm{mL}$ ( 500 copies $/ \mathrm{pL})$.

Zygote Culture. Zygotes recovered from prepubertal gilts were used in each of two replicates to evaluate the development in mouse oviduct (MO) organ culture. Oviducts were collected from immature CD1 (21- to 28-d-old) mice (Charles River Laboratories, Wilmington, MAl that were superovulated by injection of 7 IU of PMSG followed by injection of 7 IU of hCG $48 \mathrm{~h}$ later. Each female was placed with one intact male at the time of $\mathrm{hCG}$ injection. Mice that exhibited a vaginal plug the following morning were used. Oviducts were removed 20 to $22 \mathrm{~h}$ after the injection of hCG and prepared as described by Krisher et al. (1989). Zygotes that were either not injected, bufferinjected, or DNA-injected were transferred into mouse oviducts using a fine glass pipette or were maintained as controls in modified KRB medium (Davis and Day, 1978) without lactate and pyruvate (Krisher et al., 1989). Three to thirteen zygotes were transferred into the swollen ampullary region of each oviduct. Oviducts were placed on a raft of $.20-\mu \mathrm{m}$ filter paper (Tuffryn ${ }^{\circledR}$ Membrane filter, Gelman Sciences, Ann Arbor, MI) suspended in KRB. The organ culture was held at $37.5^{\circ} \mathrm{C}$ in a humidified atmosphere of $5 \% \mathrm{CO}_{2}$ in air. Mouse embryos within the oviduct were used to assess viability of the organ culture. Porcine ova classified as UFO were not microinjected but were cultured in KRB.

Porcine zygotes within $\mathrm{MO}$ were removed after either $48,72,96$, or $120 \mathrm{~h}$ of culture and placed in KRB for the remainder of the culture period. These treatments were identified as MO 48, 72, 96, and 120 , respectively. Development of zygotes cultured in KRB was visually assessed at 24-h intervals, whereas zygotes cultured in MO were assessed upon termination of organ culture and at 24-h intervals thereafter. Normal development was assumed when embryos did not fragment or remain static at one developmental stage. Duration of culture was $144 \mathrm{~h}$ (Krisher et al., 1989). Embryo development was scored using a cleavage index (CI) in which two-cell embryos equal CI of 1 , 3- to 4-cell = 2, 5- to 8-cell $=3,9$ - to 16-cell $=4$, morula $=5$, and blastocyst $=6$. 
Statistical Analysis. Variation in development of cultured zygotes was tested by two methods. Chisquare analysis was used to determine differences in the distribution of embryo CI due to microinjection or culture treatments. Least squares means and analysis of variance in CI within treatments were determined by the GLM procedure and were tested against the $F$-statistic. Nonorthogonal contrasts, tested against the improved Bonferroni $F$ statistic, were used to compare differences between treatments (SAS, 1985).

\section{Results}

Pronuclear Microinjection. Four hundred thirtysix $(72.9 \%)$ of 598 pronuclear microinjected zygotes that were cultured in vitro cleaved. Neither pronuclear microinjection nor culture method affected the proportion of zygotes that cleaved to two-cells $(P>.05)$. Only cultured zygotes that achieved a $C I \geq 1$ were included in further statistical analysis of maximum CI. Zygotes that were initially classified as UFO and attained a $\mathrm{CI}$ of 1 were considered nonmicroinjected zygotes cultured in KRB. Analysis of CI excluding UFO was similar to using them in the data set. A total of 514 zygotes with a $\mathrm{CI} \geq 1$ was included in the final data set.

Microinjection affected $(P<.01)$ maximum $C I$ attained in vitro. At $144 \mathrm{~h}$, maximum $\mathrm{CI}$ for noninjected, buffer-, or DNA-microinjected embryos was $2.93 \pm .10,2.80 \pm .13$, and $2.16 \pm .10$, respectively $(\bar{x} \pm$ SEM, Figure 1). The DNAinjected group had a lower CI $(P<.01)$ than the buffer-injected group, whereas the noninjected group had a greater CI $(P<.01)$ than the DNA injection treatment but not a greater CI than the buffer group. However, the effect of DNA microinjection was manifested by decreased development past the two-cell stage (Table 1).

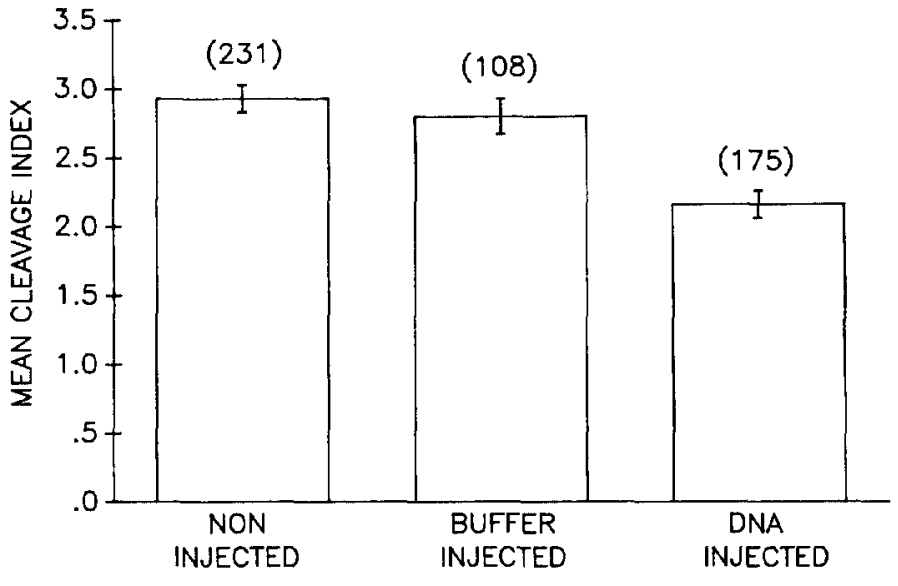

Figure 1. Mean cleavage indices attained by zygotes receiving different microinjection treatments after $144 \mathrm{~h}$ in culture. Cleavage index $1=2$-cell, $2=$ 3- to 4-cell, $3=5$ - to 8-cell, $4=9$ - to 16-cell, 5 morula, and $6=$ blastocyst. SEM are indicated by the vertical bars $(\mathrm{n})$.

Culture System. Maximum CI differed $(P<.01)$ at $144 \mathrm{~h}$. In vitro culture of zygotes in excised MO for $72 \mathrm{~h}$ resulted in the highest CI $(3.25 \pm .12)$, whereas maintaining zygotes in KRB produced the lowest $\mathrm{CI}(2.04 \pm .09$; Figure 2). Culture in excised MO for 48,96 , or $120 \mathrm{~h}$ resulted in CI of $2.66 \pm .18,2.79 \pm$ .14 , and $2.40 \pm .14$, respectively. Nonorthogonal contrasts showed that overall $\mathrm{CI}$ attained in $\mathrm{KRB}$ $(2.04 \pm .09)$ was lower $(P<.01)$ than the $\mathrm{CI}$ in $\mathrm{MO}$ $(2.77 \pm .07)$. The $\mathrm{CI}$ for MO 72 was greater $(P<.05)$ than that for MO 48, 96, and $120(P<.05)$. The interaction $(P<.01)$ of microinjection $\times$ time in oviduct culture showed that maximum $\mathrm{CI}$ was attained at $72 \mathrm{~h}$ for noninjected and DNA-injected zygotes, whereas buffer-injected zygote develop ment was greatest for $96 \mathrm{~h}$ in MO (Figure 3). At the end of each explant culture period, $79 \%$ of mouse

Table 1. Distribution of porcine zygotes obtained from superovulation of prepubertal gilts reaching specific developmental stages after 144 hours of in vitro culture in Krebs-Ringer Bicarbonate (KRB) buffer or mouse oviducts explanted in $\mathrm{KRB}^{\mathrm{a}}$

\begin{tabular}{lllcc}
\hline $\begin{array}{l}\text { Maximum } \\
\text { development }\end{array}$ & $\mathrm{CI}^{\mathrm{b}}$ & $\begin{array}{l}\text { Non- } \\
\text { injected }\end{array}$ & $\begin{array}{l}\text { Buffer- } \\
\text { injected }\end{array}$ & $\begin{array}{l}\text { DNA- } \\
\text { injected }\end{array}$ \\
\hline 2-cell & 1 & $10.4(24)^{\mathrm{c}}$ & $8.3(9)$ & $30.9(54)$ \\
3- to 4-cell & 2 & $47.6(110)$ & $41.7(45)$ & $40.6(71)$ \\
5- to 8-cell & 3 & $26.6(62)$ & $36.1(39)$ & $20.0(35)$ \\
9- to 16-cell & 4 & $3.6(13)$ & $.9(1)$ & $3.4(6)$ \\
Morulae & 5 & $2.2(5)$ & $4.6(5)$ & $.6(1)$ \\
Blastocysts & 6 & $7.4(17)$ & $8.3(9)$ & $4.6(8)$ \\
Total & - & $(231)$ & $(108)$ & $(175)$ \\
\hline
\end{tabular}

${ }^{2}$ Chi-square $P<.01$ between treatments.

b Cleavage index.

cPercentage and (number). 


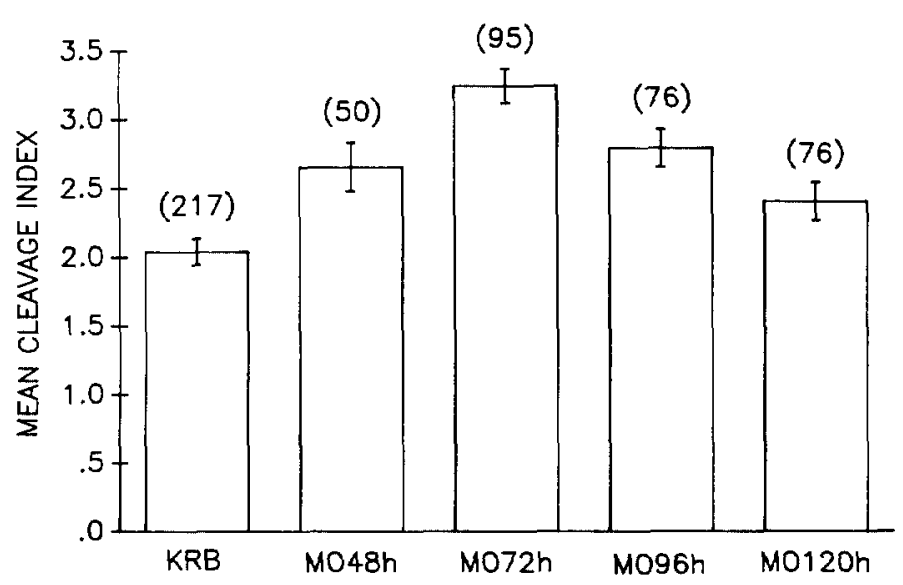

Figure 2. Mean cleavage indices attained by zygotes after $144 \mathrm{~h}$ in different culture systems. Legend abbreviations are as follows: KRB is Krebs-Ringer bicarbonate buffer, M048h is $48 \mathrm{~h}$ in mouse oviduct culture, M072h is $72 \mathrm{~h}$ in mouse oviduct culture, M096h is $96 \mathrm{~h}$ in mouse oviduct culture, and M0120h is $120 \mathrm{~h}$ in mouse oviduct culture. Embryos were removed from mouse oviducts at the indicated times and further cultured in KRB alone for the duration of the culture. SEM are indicated by the vertical bars (n).

oviducts had normal, stage-specific, developing mouse embryos (e.g., mouse embryos were fourcell at MO 48 ).

\section{Discussion}

The observation that injection of DNA impaired development compared with buffer injection or no injection suggests either that DNA, not merely the mechanical procedure of pronuclear injection, was altering the pronulcear environment or that the DNA construct was being integrated into vitai regions of the genome in such a way that development was inhibited. It is possible that chemical and physical contamination of the DNA could contribute components that could be detrimental to development. Hammer et al. (1986) reported that DNA microinjection decreased zygote survival to the blastocyst stage by approximately $50 \%$ in both sheep and swine compared with noninjected controls. Robl and First (1985) found that development of pronuclear microinjected mouse zygotes to the morula or blastocyst stage was not affected by DNA injection, buffer injection, or by inserting the tip of the pipette into the pronucleus with no injection. However, development was less than in those that experienced no manipulation. The exact mechanism(s) by which DNA microinjection causes embryonic death is not known. Surprisingly, the microinjection event alone did not inhibit in vitro develop- ment of porcine zygotes. These results contrast with work reported in mice (Brinster et al., 1985) that injection of buffer alone decreases in vitro embryo development similar to DNA injection, suggesting that porcine zygotes are more resilient than mouse zygotes.

Bavister (1988) noted that in non-rodent species, developmental block of embryos maintained in vitro tended to occur at the stage at which the embryos move out of the oviduct and into the uterus in vivo. Our data show that the culture of porcine zygotes in the oviduct of a mouse for as little as $48 \mathrm{~h}$ allowed development past the fourcell block, which was not attained by culture in KRB alone. However, coculture within MO for $72 \mathrm{~h}$ was necessary for maximal zygote development. Development of zygotes held in MO for 96 and 120 $h$ was lower than that of zygotes held in $\mathrm{MO}$ for 72 $h$, suggesting that the oviduct culture environment was not adequate for later stages of porcine embryo development. The lower zygote development could be due to an inappropriate environment present in $\mathrm{MO}$ that cannot support porcine embryos. This may also be indicative of decreased viability of oviductal cells in organ culture. Dying cells would release substances that could adversely affect embryo viability. The percentage of morula and blastocyst development (22\%) for our noninjected prepubertal zygotes was lower than

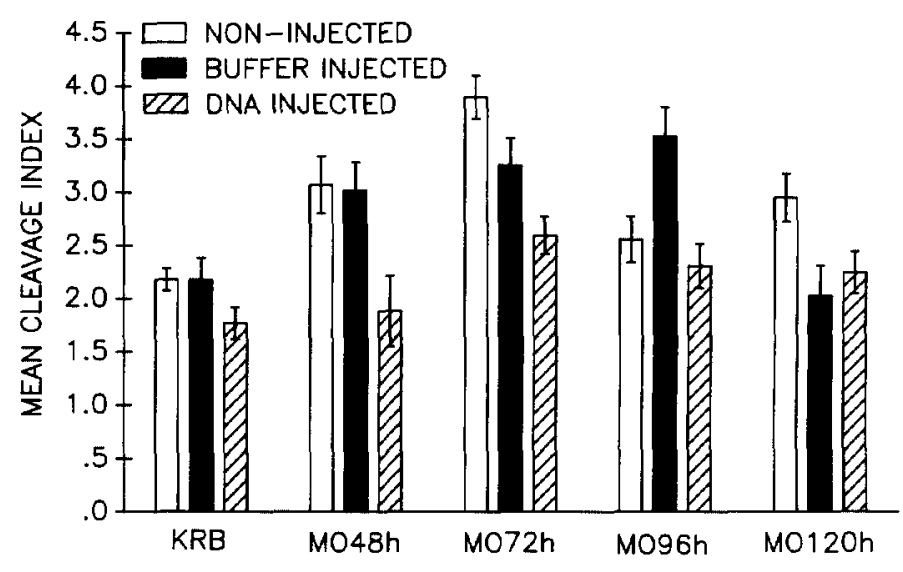

Figure 3. Mean cleavage indices for zygotes after 144 $h$ in culture that were untreated or injected with buffer or DNA. Microinjection by mouse oviduct interaction was significant $(P<.01)$. Legend abbreviations are as follows: $\mathrm{KRB}$ is Krebs-Ringer bicarbonate buffer, M048h is $48 \mathrm{~h}$ in mouse oviduct culture, M072h is $72 \mathrm{~h}$ in mouse oviduct culture, M096h is $96 \mathrm{~h}$ in mouse oviduct culture, and $\mathrm{M} 0120 \mathrm{~h}$ is $120 \mathrm{~h}$ in mouse oviduct culture. Embryos were removed from mouse oviducts at the indicated times and further cultured in KRB alone for the duration of the culture. SEM are indicated by the vertical bars. 
the $78 \%$ reported by Krisher et al. (1989) using the same MO culture system and lower than the 45 to $60 \%$ morula and blastocyst development in a more recent report by Petters et al. (1990). Both of these studies used one- and two-cell porcine embryos obtained from sows that were not synchronized or superovulated. The lower embryonic developmental rate may be related to differences in follicular development, which may affect subsequent embryonic development. Wiesak et al. (1990) reported a dissimilar pattern of follicular development in PMSG- and hCG-treated, immature gilts compared with naturally cycling pigs. Also, porcine zygote development in vitro was greater when zygotes were collected from mature gilts than when they were collected from prepubertal gilts (Pinkert et al., 1989).

\section{Implications}

Maintaining porcine zygotes within explanted mouse oviducts for as little as $48 \mathrm{~h}$ allows significantly improved development compared with culture in medium alone. When considering the detrimental effect of pronulcear microinjection, the impairment to development was found to be caused by the injection of DNA and(or) possible contaminants and not by the mechanical process of microinjection itself.

\section{Literature Cited}

Andres, A. C., C. A. Schonenberger, B. Groner, L. Hennighausen, L. LeMeur, and P. Gerlinger. 1987. Ha-ras oncogene expression directed by a milk protein gene promoter: Tissue specificity, hormonal regulation, and tumor induction in transgenic mice. Proc. Natl. Acad. Sci. USA 84:1299.
Bavister, B. D. 1988. Role of oviductal secretions in embryonic growth in vivo and in vitro. Theriogenology 29:143.

Brinster, R. L., H. Y. Chen, M. E. Trumbauer, M. K. Yagle, and R. D. Palmiter. 1985. Factors affecting the efficiency of introducing foreign DNA into mice by microinjecting eggs. Proc. Natl. Acad. Sci. USA 82:4438.

Davis, D. L., and B. N. Day. 1978. Cleavage and blastocyst formation by pig eggs in vitro. J. Anim. Sci. 46:1043.

Hagan, D. R., R. S. Prather, M. M. Sims, and N. L. First. 1991. Development of one-cell porcine embryos to the blastocyst stage in simple media. J. Anim. Sci. 69:1147.

Hammer, R. E., V. G. Pursel, C. E. Rexroad, Jr., R. J. Wall, D. J. Bolt, R. D. Palmiter, and R. L. Brinster. 1986. Genetic engineering of mammalian embryos. J. Anim. Sci. 63:269.

Krisher, R. L., R. M. Petters, B. H. Johnson, B. D. Bavister, and A. E. Archibong. 1989. Development of porcine embryos from the one-cell stage to blastocyst in mouse oviducts maintained in organ culture. J. Exp. Zool. 249:235.

Petters, R. M., B. H. Johnson, M. L. Reed, and A. E. Archibong. 1990. Glucose, glutamine and inorganic phosphate in early development of the pig embryo in vitro. J. Reprod. Fertil. $89: 269$.

Pinkert, C. A., D. L. Kooyman, A. Baumgartner, and D. H. Keister. 1989. In-vitro development of zygotes from superovulated prepubertal and mature gilts. J. Reprod. Fertil. 87:63.

Robl, J. M., and N. L. First. 1985. Manipulation of gametes and embryos in the pig. J. Reprod. Fertil. (Suppl)) 33:101.

SAS. 1985. SAS User's Guide: Statistics. SAS Inst. Inc., Cary, NC.

Velander, W. H., R. L. Page, T. Morcol, C. G. Russell, R. Canseco, J. M. Young, W. N. Drohan, F. C. Gwazdauskas, T. D. Wilkins, and J. L. Johnson. 1992. Production of biologically active human protein $\mathrm{C}$ in the milk of transgenic mice. Ann. N.Y. Acad. Sci. (In press).

Wall, R. J., V. G. Pursel, R. E. Hammer, and R. L. Brinster. 1985. Development of porcine ova that were centrifuged to per. mit visualization of pronuclei and nuclei. Biol. Reprod. 32: 645.

Wiesak, T., M. G. Hunter, and G. R. Foxcroft. 1990. Differences in follicular morphology, steroidogenesis and oocyte maturation in naturally cyclic and PMSG/hCG-treated prepubertal gilts. J. Reprod. Fertil. 89:633.

White, K. L., K. Hehnke, L. F. Rickords, L. L. Southern, D. L. Thompson, Jr., and T. C. Wood. 1989. Early embryonic development in vitro by coculture with oviductal epithelial cells in pigs. Biol. Reprod. 41:425. 